\title{
INFLUÊNCIA DO USO E OCUPAÇÃO DO SOLO NA QUALIDADE DA ÁGUA NA BACIA DO RIO PERUÍPE, ITANHÉM E JUCURUÇU
}

\author{
AUTOR: BENTO SANTOS DE BRITO JUNIOR \\ CO-AUTOR/ORIENTADOR: JOAO BATISTA LOPES DA SILVA
}

\begin{abstract}
Resumo: As práticas de uso da terra agrícola e urbana, a utilização da água do lençol freático para abastecimento e irrigação, tem contribuído para alterações no ciclo hidrológico como também, no regime hidrológico dos rios. Para a mensuração de tais alterações, são feitas análises estatísticas de séries temporais que é uma das mais importantes ferramentas em hidrologia. Com este trabalho objetiva-se analisar o grau de influência do uso e ocupação do solo com a qualidade da água nas bacias hidrográficas dos rios Peruípe, Itanhém e Jucuruçu. Utilizando-se de postos de monitoramento de qualidade da água e dados de mapeamentos. Os dados de qualidade da água foram extraídos do site do Inema, enquanto os de uso e ocupação do solo no site Mapbiomas. As áreas de maior significância no uso do solo da bacia, são as áreas de pastagem, que somadas as áreas de floresta plantada e agricultura nos levam a concluir que a área da bacia demonstra predominância em áreas antropizadas desde 1985. O coliforme termotolerantes é o parâmetro que mais causa assombro, por estar presente em todas as análises da qualidade da água das sub-bacias. A presença do homem no campo afeta a qualidade dos recursos d'água a medida em que faz uso do solo de maneira desordenada, ao retirar a vegetação nativa em áreas de recarga da bacia, entre tantas outras maneiras. Estudos que visem minimizar os impactos causados pelo homem devem ser cada vez mais estimulados para assegurar a água em qualidade e quantidade disponível.
\end{abstract}

Palavras-chave: Uso e ocupação, qualidade da água, bacia hidrológica, rio Peruípe, rio. 